\begin{tabular}{|c|c|}
\hline $\begin{array}{l}\text { JUL } 081996(21 \text { ENGINEERING DATA TRANSMITTAL } \\
\text { Sta. } 21\end{array}$ & 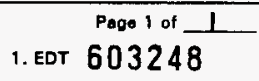 \\
\hline
\end{tabular}

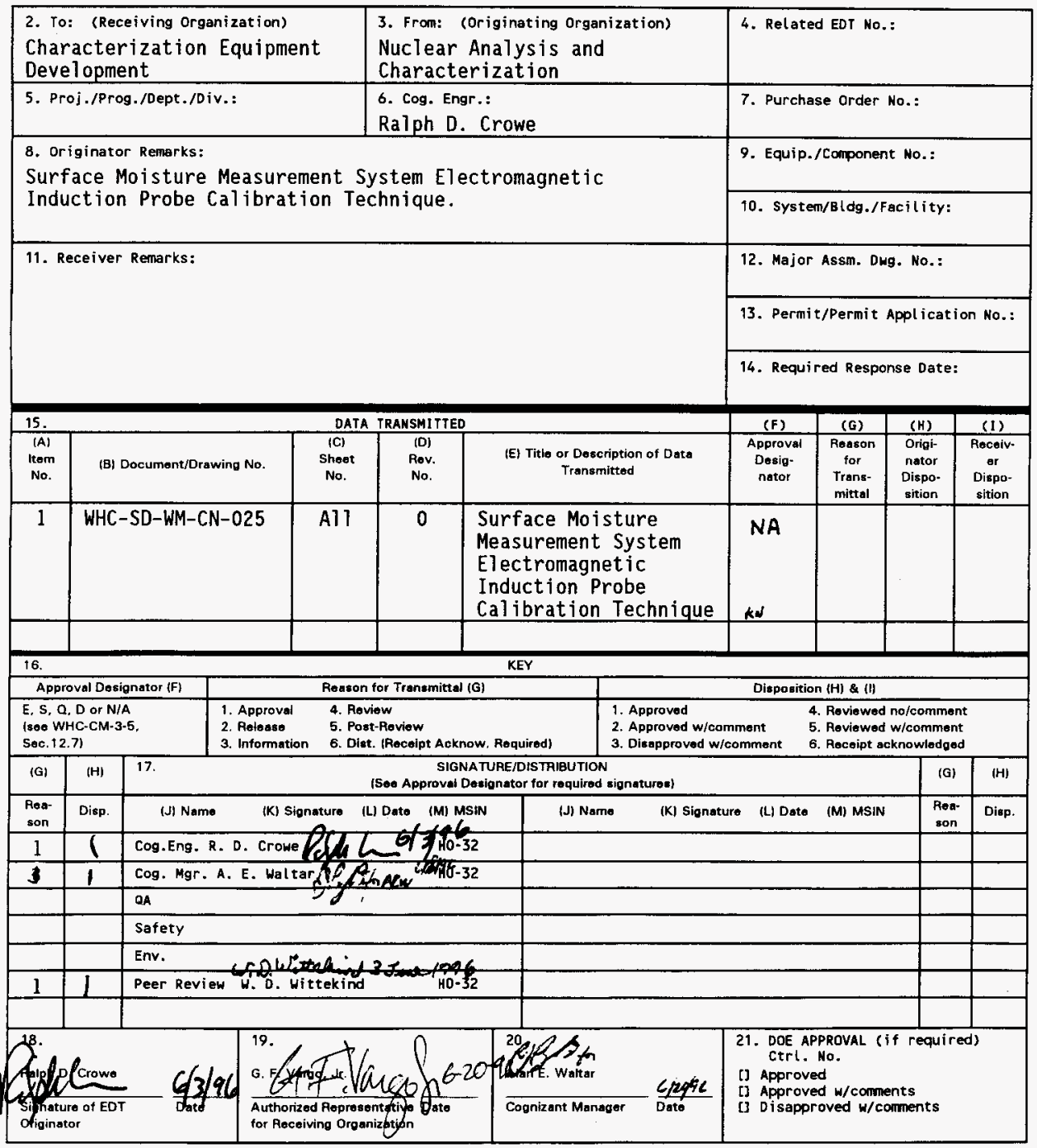

BD-7400-172-2 (04/94) GEF097 


\section{SURFACE MOISTURE MEASUREMENT SYSTEM ELECTROMAGNETIC INDUCTION PROBE CALIBRATION TECHNIQUE}

Ralph D. Crowe

West inghouse Hanford Company, Richland, WA 99352

U.S. Department of Energy Contract DE-AC06-87RL10930

$\begin{array}{llll}\text { EDT/ECN: } & 603248 \text { *N } & \text { UC: } 2000 \mathrm{kN} \\ \text { Org Code: } & 8 M 720 & \text { Charge Code: } & N 2210 \\ \text { B\&R Code: } & E w 313000002 & \text { Total Pages: } & 18 \\ \text { KN }\end{array}$

Key Words: Surface Moisture Measurement System (SMMS)

Electromagnetic Induction (EMI)

Abstract:

The Surface Moisture Measurement System (SMMS) is designed to measure the moisture concentration near the surfaces of the wastes located in the Hanford site tank farms. This document describes a calibration methodology to demonstrate that the Electromagnetic Induction (EMI) moisture probe meets relevant requirements in the Design Requirements Document (DRD) for the Surface Moisture Measurement System (Stokes et a1. 1995). The primary purpose of the experimental tests described in this methodology is to make possible interpretation of EMI in-tank surface probe data to estimate the surface moisture.

TRADEMARK DISCLAIMER. Reference herein to any specific comercial product, process, or service by trade name, trademark, manufacturer, or otherwise, does not necessarily constitute or imply its endorsement, recommendation, or favoring by the United States Government or any agency thereof or its contractors or subcontractors.

Printed in the United States of America. To obtain copies of this document, contact: WHC/BCS Document Control Services, P.0. Box 1970, Mailstop H6-08, Richland WA 99352, Phone (509) 372-2420; Fax (509) 376.4989.
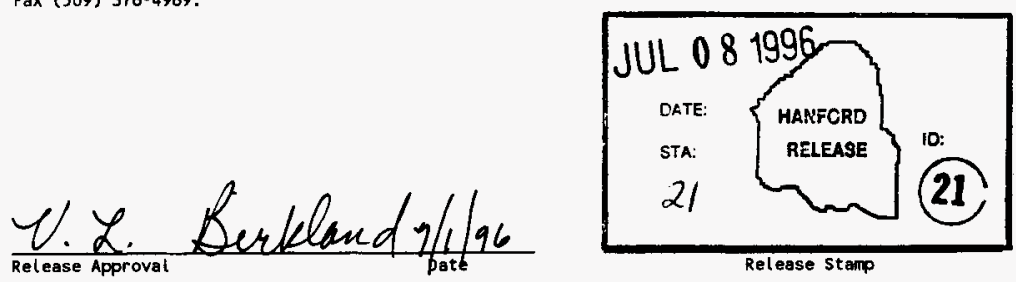

Approved for Public Release 
WHC-SD-WM-CN-025, Rev. O

KN

SURFACE MOISTURE MEASUREMENT SYSTEM

ELECTROMAGNETIC INDUCTION PROBE

CALIBRATION TECHNIQUE

Ralph D. Crowe 
WHC-SD-WM-CN-025, Rev. 0

Table of Contents

1.0 INTRODUCTION. . . . . . . . . . . . . . . . 1

2.0 STANDARD PREPARATION. . . . . . . . . . . . . . 1

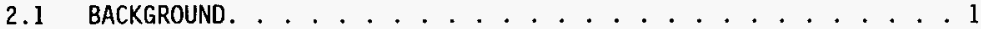

2.2 MATERIALS, SIZES, GEOMETRY, AND LIST OF

CALIBRATION STANDARDS ............. . . . .

2.3 METHODOLOGY FOR PREPARATION OF STANDARD SOLUTIONS . . . . . . . 2

2.3.1 Material Surrounding Standards for Infinite

Detector Response ............. 2

2.3.2 Calibration of Measurement Tools and Instruments. . . . . 2

2.3.3 Mixing of Solutions .............. . . 3

3.0 SURFACE MOISTURE MEASUREMENT SYSTEM VERIFICATION. . . . . . . 3

3.1 DESCRIPTION OF PROBE AND DATA ACQUISITION SYSTEM. . . . . . 3

3.2 EXPERIMENTAL METHODOLOGY. . . . . . . . . . . . . 3

3.2.1 Safe Operation and Handling . . . . . . . . . . 3

3.2 .2 Setup and Turn on .............. . . . . .

3.2.3 Temperature Mesurements and Equilibrium . . . . . . 4

3.2.4 Calibration Data Collection ............ . 4

3.2.5 Data Storage and Archival ............ . 4

3.2.6 Data Comparison with Calculations ......... 5

4.0 TEMPERATURE DEPENDANCE TESTS. . . . . . . . . . . . 5

4.1 EXPECTED CONDITIONS FOR THE EMI PROBE .......... 5

4.2 DETECTOR GAMMA-RAY EXPOSURE TESTS . . . . . . . . . . . 5

4.3 TEMPERATURE TESTS ................. 5

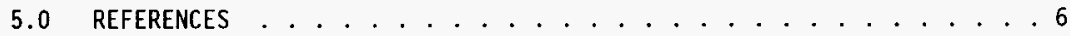


WHC-SD-WM-CN-025, Rev. 0

\section{Appendix}

A. SODIUM CHLORIDE MSDS. . . . . . . . . . . . . . . 7
B. POTASIUM CHLORIDE MSDS. . . . . . . . . . . . . . 11 
WHC-SD-WM-CN-025, Rev. 0

\section{SURFACE MOISTURE MEASUREMENT SYSTEM \\ ELECTROMAGNETIC INDUCTION PROBE \\ CALIBRATION TECHNIQUE}

\subsection{INTRODUCTION}

The Surface Moisture Measurement System (SMMS) is designed to measure the moisture concentration near the surfaces of the wastes located in the Hanford site tank farms. This document describes a calibration methodology to demonstrate that the Electromagnetic Induction (EMI) moisture probe meets relevant requirements in the Design Requirements Document (DRD) for the Surface Moisture Measurement System (Stokes et al. 1995). The primary purpose of the experimental tests described in this methodology is to make possible interpretation of EMI in-tank surface probe data to estimate the surface moisture.

\subsection{STANDARD PREPARATION}

In order to interpret data from the SMMS one must have a way of determining the response of the EMI instrumentation to moisture in material similar to the waste encountered in the tanks. It is not possible to perform the calibrations on actual waste because the waste is radioactive and the actual moisture content is not controlled. The waste will be simulated using containers of liquids with known electrical conductivities. This process will also be used to support the calculational models of the EMI probe response.

\subsection{BACKGROUND}

The electromagnetic induction (EMI) probe is being developed to measure the amount of water remaining in waste stored in the high-level waste tanks (Wittekind and Crowe 1996). It uses a magnetic field to induce electrical currents in the surrounding waste proportional to the waste electrical conductivity. The waste moisture is estimated based on the measured waste conductivity. The purpose of these tests are to determine the response of the EMI as a function of waste electrical conductivity, depth of penetration into the waste and probe lift off. Lift off is the term used to identify the distance between the probe and the surface of the waste. The data measured from the standards will allow determination of the average moisture concentration and development of a method to estimate the profile of the moisture concentration for the actual tanks.

Results of initial probe design development using both computer modeling and prototype testing may be found in Electromagnetic Induction Probe Calibration for Conductivity Measurements and Moisture Content Determination of Hanford High Level Waste (Wittekind and Crowe 1996). 


\subsection{MATERIALS, SIZES, GEOMETRY, AND LIST OF CALIBRATION STANDARDS}

The calibration standards solutions are contained in $10 \mathrm{gallon}$ ( 37.85 liter) cylindrical polyethylene tanks $(33 \mathrm{~cm}$ diameter, $50.8 \mathrm{~cm}$ high). The tanks will be systematically filled with solutions of known conductivities to measure and calibrate the response of the EMI probe. Additional tanks will be used to prepare and store conducting liquids. Although at least six solutions with different conductivities will be prepared, only two to three storage tanks will be required. The conductivity of a prepared solution is easily measured with a conductivity probe, therefore, the solution with the different conductivities will be prepared as needed.

The conductivity of the liquid is adjusted by adding measured quantities of salt to water. Solutions with conductivities from $0 \mathrm{mS} / \mathrm{cm}$ to $100 \mathrm{mS} / \mathrm{cm} w i 1$ be measured. At least two different salts will be used: sodium chloride and potassium chloride.

\subsection{METHODOLOGY FOR PREPARATION OF STANDARD SOLUTIONS}

\subsection{Material Surrounding Standards for Infinite Detector Response}

Experience indicates that, especially for the low moisture standards, structures outside of the calibration tanks may influence the probe responses (Crowe and Wittekind 1995). While these influences are expected to be relatively small, they need to be minimized. The tanks, while being used, will be isolated from nearby structures such as the concrete floor and nearby metal structures by a distance of at least $25 \mathrm{~cm}$ (10 in).

\subsubsection{Calibration of Measurement Tools and Instruments}

The tools that will be used in these tests that will need calibration are the following:

- Scale for weighing individual salt samples $(100 \mathrm{~g} \pm 0.1 \mathrm{~g})$

- Linear scale for measuring the heights of fills $(60 \mathrm{~cm} \pm 0.1 \mathrm{~cm})$

- Graduated volume for measuring the volume of 1iquid additions (1000 $\mathrm{ml} \pm 10 \mathrm{ml}$ )

- Temperature compensated electrical conductivity probe $(0-100 \mathrm{mS} / \mathrm{cm})$

- MIZ-40A, Eddy Current Test Instrument (ZETEC 1995a)

- DDR-1, Data Recorder (ZETEC 1995b)

The model name and serial number of each calibrated tool used in the preparation or tests will be recorded in an appropriate logbook. A copy of the current calibration sheet, when applicable, will also be obtained and placed in a logbook. 
WHC-SD-WM-CN-025, Rev. D

\subsubsection{Mixing of Solutions}

The materials will be mixed in a storage tank. The tank will be cleaned and dried before mixing of the solution. The required quantity of the salt will be weighed and poured into the storage vessel. Water will be added to the vessel and stirred with a mixer. The mixer will be run for about 5 minutes and the conductivity measured. The conductivity will be adjusted by either adding salt or water until the desired conductivity is obtained. The room temperature will be recorded on the day of mixing. A description of the preparation of the solution including amount of salt and water used, will be recorded for each solution as mixed. The solution will be considered homogeneous when the electrical conductivity measurement following the stirring of the tank gives the same conductivity value for three sequential stirrings.

\subsection{SURFACE MOISTURE MEASUREMENT SYSTEM VERIFICATION}

\subsection{DESCRIPTION OF PROBE AND DATA ACQUISITION SYSTEM}

The EMI probe consists of a cylindrical polyethylene tube $(8.9 \mathrm{~cm} \mathrm{OD})$ containing two identical wire coils. A alternating signal is sent to both coils via a pair of coaxial cables from the MIZ-40A analyzer (ZETEC 1995a). The MIZ-40A compares and quantifies the difference between the signals from the reference coil and the coil near the surface of the waste. The amplitude and phase information from the differential signal is recorded for interpretation as waste moisture content.

\subsection{EXPERIMENTAL METHODOLOGY}

\subsubsection{Safe Operation and Handling}

The primary potential safety hazards are mechanical hazards associated with the fifting of heavy objects and with the use of a mixer and mechanical pump. The EMI probe does not introduce any unique safety hazards. The safety concerns during the testing with the Surface Moisture Monitoring Systems (SMMS) EMI probe are for the handling of chemical solutions and use of electrical equipment. The Material Specification Data Sheets (MSDS) will be posted for the salt solutions used. The chemical salts were selected because they are familiar and common compounds with minimal hazard. Normal electrical safety precautions regarding the handing of electrical equipment will minimize the electrical hazard.

\subsubsection{Setup and Turn on}

The EMI probe will be connected, via the signal/support cable, to the MIZ-40A analyzer and DDR-1 data recorder (Zetec 1995b). The signal circuit will include the probe related circuit components (intrinsic safety barriers, connectors, cable and slip ring) as will be used in the field. The MIZ-40A analyzer is used to obtain and process the probe signals. The analyzer also provides the driving signal to the probe, through intrinsically safe 


$$
\text { WHC-SD-WM-CN-025, Rev. } 0
$$

electrical barriers. The intrinsic barrier requires a few minutes after the signal is applied to the probe to reach a stable (no drifting) condition. The probe signal null will be monitored to identify when a stable condition has been reached and the length of time required to reach this condition will be noted.

\subsubsection{Temperature Measurements and Equilibrium}

The temperature of the probe should have $1 \mathrm{ittle}$ effect upon the electrical circuit response. However, since the electrical conductivity of the salt solutions change with temperature, it is important to know the temperature of the surrounding media. Since the conductivity meters to be used are temperature compensated, they also provide the solution temperature. Calibration tests for the conductivity meters will be performed using standard solutions providing traceability to National Institute of Standards and Technology (NIST) temperature standards. Temperature equilibrium will be defined as all probe measuring less than a $1^{\circ} \mathrm{C}$ change in temperature over a time interval of 5 minutes.

\subsubsection{Calibration Data Collection}

Detector response data will be collected and recorded for each prepared electrical conductivity solution. A logbook will be maintained that provides a record of measured detector responses for each solution. This information will include the following information:

- date and time of day,

- temperature of room,

- volume of solution prepared,

- weight of all salts mixed into solution, and

- temperature and conductivity of the solution,

- intrinsic barrier data collection time interval,

- front panel settings for the MIZ-40A analyzer,

- DDR-1 data file index number,

- depth (or volume) of the liquid,

- height of probe above surface, and

- magnitude and phase of the measured signal.

The raw data collected by the analyzer will be stored electronically in indexed files on DDR-1 Data Recorder.

In addition to acquiring the probe response using the solutions, the response of the isolated probe will be measured. For this measurement, the probe will be suspended in air at least $50 \mathrm{~cm}$ from the floor or any walls. With the probe essentially isolated from outside materials that could provide signal to the probe, a measurement of the detector response will be made.

\subsubsection{Data Storage and Archival}

Data storage will initially be in a Data Logbook for most data. Data collected electronically using the removable hard drive on the analyzer data recorder. This data can be later transferred to a computer with access to the WHC common file storage for archival. A summary of the data collected will be included in the calibration report document. 


$$
\text { WHC-SD-WM-CN-025, Rev. } 0
$$

included in the calibration report document.

\subsubsection{Data Comparison with Calculations}

The EMI probe measurements will be compared to calculational model predictions to demonstrate it is functioning as designed. The primary model input parameters are the geometry and material properties of the probe and the standards. Physical dimensions, within mechanical tolerances, may need to be adjusted in each part of the geometry to obtain best agreement with measured results.

\subsection{TEMPERATURE DEPENDANCE TESTS}

The insensitivity of the EMI probe to elevated temperatures needs to be demonstrated. The experiments described here will demonstrate the effect of temperature and should provide information that will enable corrections to be applied to in-tank data based upon temperature data if needed.

\subsection{EXPECTED CONDITIONS FOR THE EMI PROBE}

While the EMI probes are expected to operate in a field of up to $50 \mathrm{R}$ and temperatures up to $45-50^{\circ} \mathrm{C}$, these conditions should have no effect on the probe response. The tests described here are to demonstrate the insensitivity of the probe to this range of conditions.

\subsection{DETECTOR GAMMA-RAY EXPOSURE TESTS}

No gamma ray tests will be performed. Unlike the neutron moisture probe, the gamma field does not affect the EMI probe signal. The EMI electronics are in the MIZ-40A which is remote from gamma field. The voltage across the EMI coil is less than the 16 volts peak to peak voltage source in the MIZ-40A. The electrical circuit in the EMI probe in a simple device using only coils of wire without any discrete electrical components. For these reasons, there is no expected gamma effect. Material specifications for the materials used in the construction of the EMI probe will be used to demonstrate that the accumulated gamma fluence will not degrade the probe function within the 1 ifetime of the EMI.

\subsection{TEMPERATURE TESTS}

A thermal blanket is to be wrapped around the each detector for the temperature dependence measurement. The probe response will be measured and recorded before the heater is turned on. The probe temperature probe will raised using the heater and the probe response and temperature will be measured and recorded. The probe will be allowed to cool down and a final measurement made. 


$$
\text { WHC-SD-WM-CN-025, Rev. } 0
$$

\subsection{REFERENCES}

Crowe, R. D. And W. D. Wittekind, 1995, Ferrocyanide Safety Program: In-Tank Application of Electromagnetic Induction (EMI) Moisture Measurements FY 1995 Report, WHC-SD-WM-ER-520 Rev. 0,

Stokes, T. I., W. T. Watson, M. Gimera, J. H. Bussell, A. Dabiri, D. T. Holslin, F. Johansen, 1995, Design Requirements Document (DRD) for Surface Moisture Measurement System (SMMS), WHC-SD-WM-DRD-002, Rev. 0. , Westinghouse Hanford Company, Richland, Washington.

W. D. Wittekind and R. D. Crowe, 1996, Electromagnetic Induction Probe Calibration for Electrical Conductivity nd Moisture Content Determination of Hanford High Level Waste, WHC-SD-WM-ER-531 Rev. 0., Westinghouse Hanford Company, Richland, Washington.

ZETEC, 1995a, MIZ-40A, Eddy Current Test Instrument, Operating Guide, Zetec Inc, Issaquah, Washington.

ZETEC, 1995b, DDR-1, Data Recorder, Operating Guide, Zetec Inc, Issaquah, Washington. 
WHC-SD-WM-CN-025, Rev. 0

APPENDIX A

Sodium Chloride MSDS 


\section{Appendix A - Sodium Chloride MSDS}

Sigma Chemical Co. P.O. Box 14508

St. Louis, MO 63178

Phone: $314-771-5765$
Aldrich Chemical Co., Inc. 1001 West St. Paul

Milwaukee, WI 53233

Phone: 414-273-3850
Fluka Chemical Corp. 980 South Second St. Ronkonkoma, NY 11779 Phone: 516-467-0980

Emergency Phone: 516-467-3535

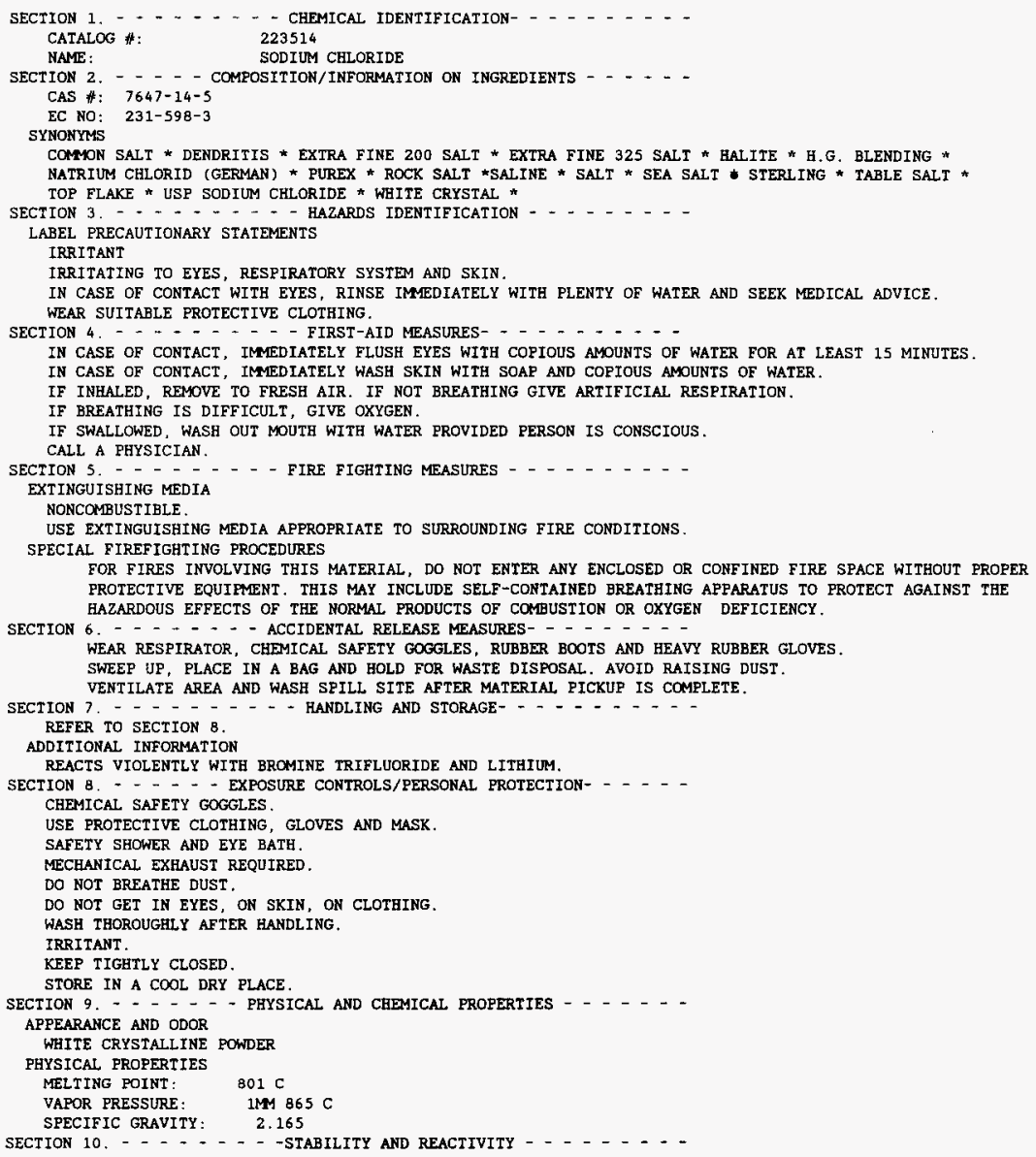


INCOMPATIBILITIES

STRONG OKIDIZING AGENTS

STRONG ACIDS

PROTECT FROM MOISTURE.

HAZARDOUS COMBUSTION OR DECOMFOSITION PRODUCTS

NATURE OF DECOMPOSITION PRODUCTS NOT KNOWN.

SECTION 11. - - . - . TOXICOLOGICAL INFORMATION - . - . -

ACUTE EFFECTS

MAY BE HARMFUL BY INHALATION, INGESTION, OR SKIN ABSORPTION.

CAUSES EYE IRRITATION.

CAUSES SKIN IRRITATION.

MATERIAL IS IRRITATING TO MUCOUS MEMBRANES AND UPPER

RESPIRATORY TRACT

RTECS \#: VZ4725000

SODIUM CHLORIDE

IRRITATION DATA

SKN-RBT 50 MG/24H MLD BIOFX* 20-3/71

SKN-RBT $500 \mathrm{MG} / 24 \mathrm{H}$ MLD $28 \mathrm{PPAK}-, 7,72$

$\begin{array}{ll}\text { EYE-RBT } 100 M G \text { MLD } & \text { BIOFX* 20-3/71 }\end{array}$

EYE-RBT 100 MG/24H MOD 28ZPAK $-, 7,72$

EYE-RBT 10 MG MOD TXAPA9 $55,501,80$

TOXICITY DATA

ORL-RAT LDSO:3 GM/KG

IHL-RAT LC50:>42 GM/M3/1H

TXAPA9 $20,57,71$

ORL-MUS LDSO:4 GM/KG

IPR-MUS LD50:6614 MG/KG

BIOFX* 20-3/71

FRPPAO $27,19,72$

SCU-MUS LD50:3 GM/KG

COREAF $256,1043,63$

ARZNAD $7,445,57$

IVW-MUS LD50:645 MG/KG

ARZNAD $7,445,57$

ICV-MUS LD50:131 MG/KG TYKNAQ 27,131,80

SKN-RBT LD50:>10 GM/KG BIOFX* 20-3/71

TARGET ORGAN DATA

BEHAVIORAL (SOMNOLENCE)

BEHAVIORAL (CONVULSIONS OR EFFECT ON SEIZURE THRESHOLD)

BEHAVIORAL (MUSCLE CONTRACTION OR SPASTICITY)

CARDIAC (OTHER CHANGES)

ENDOCRINE (ESTROGENIC)

MATERNAL EFFECTS (OVARIES, FALLOPIAN TUBES)

MATERNAL EFFECTS (OTHER EFFECTS ON FEMALE)

EFFECTS ON FERTILITY (PRE-IMPLANTATION MORTALITY)

EFFECTS ON FERTILITY (POST-IMPLANTATION MORTALITY)

EFFECTS ON FERTILITY (ABORTION)

EFFECTS ON EMBRYO OR FETUS (FETOTOXICITY)

EFFECTS ON EMBRYO OR FETUS (FETAL DEATH)

SPECIFIC DEVELOPMENTAL ABNORMALITIES (MUSCULOSKELETAL SYSTEM)

ONLY SELECIED REGISTRY OF TOXIC EFFECTS OF CHEMICAL, SUBSTANCES

(RTECS) DATA IS PRESENTED HERE. SEE ACTUAL ENTRY IN RTECS FOR COMPLETE INFORMATION .

SECTION 12. . . - . ECOLOGICAL INFORMATION - . . . . DATA NOT YET AVAILABLE.

SECTION 13. - - - - - - DISPOSAL CONSIDERATIONS - - - - . CONTACT A LICENSED PROFESSIONAL WASTE DISPOSAL SERVICE TO DISPOSE OF THIS MATERIAL.

OBSERVE ALL FEDERAL, STATE AND LOCAL ENVIRONMENTAL REGULATIONS.

SECTION 14. - . - - - - TRANSPORT INFORMATION - - - . - CONTACT SIGMA CHEMICAL COMPANY FOR TRANSFORTATION INFORMATION.

SECTION 15. - ...... - REGULATORY INFORMATION - . . . . -

EUROPEAN INFORMATION

IRRITANT

R $36 / 37 / 38$

IRRITATING TO EYES, RESPIRATORY SYSTEM AND SKIN.

S 26

IN CASE OF CONTACT WITH EYES, RINSE IMEDIATELY WITH PLENTY OF

WATER AND SEEK MEDICAL ADVICE.

S 36

WEAR SUITABLE PROTECTIVE CLOTHING.

REVIEWS, STANDARDS, AND REGULATIONS

OEL $M$ MAK

EPA FIFRA 1988 PESTICIDE SUBJECT TO REGISTRATION OR RE-REGISTRATION FEREAC $54,7740,89$

NOHS 1974: HZD 68880; NIS 265; TNF 63391; NOS 163; TNE 630453

NOES 1983; HZD E0256; NIS 1; TNF 403; NOS 5; TNE 4029; TFE 2015

NOES 1983: HZD 68880; NIS 336; INE 69628; NOS 211; TNE 1743954; TFE 
WHC-SD-WM-CN-025, Rev. O

817249

ERA GENETOX PROGRAM 1988, NEGATIVE: IN VITRO CYTOGENETICS-NONHUMAN. SPERM MORPHOLOGY-MOUSE

EPA GENETOX PROGRAM 1988, INCONCLUSIVE: MAMALIAN MICRONUCLEUS

EPA TSCA SECTION $B(B)$ CHEMICAL INVENTORY

EPA TSCA SECTION B(D) UNPUBLISHED HEALTH/SAFETY STUDIES

EPA TSCA SECTION 8(E) RISK NOTIFICATION, BEHQ-0B92-9201

EPA TSCA TEST SUBMISSION (TSCATS) DATA BASE, OCTOBER 1995

SECTION 16. - - - - - - - OTHER INFORMATION - - - - . - . - -

THE ABOVE INFORMATION IS BELIEVED TO BE CORRECT BUT DOES NOT FURFORT TO

BE ALL INCLUSIVE AND SHALL BE USED ONLY AS A GUIDE. SIGMA, AIDRICH,

FLUKA SHALL NOT BE HELD LIABLE FOR ANY DAMAGE RESULTING FROM HANDLING

OR FROM CONTACT WITH THE ABOVE PRODUCT, SEE REVERSE SIDE OF INVOICE OR

PACKING SLIP FOR ADDITIONAL TERMS AND CONDITIONS OF SALE,

COPYRIGHT 1996 SIGMA CHEMICAL CO., ALDRICH CHEMICAL CO, INC.,

FLUKA CHEMIE AG

LICENSE GRANTED TO MAKE UNLIMITED PAPER COPIES FOR INTERNAL USE ONLY 
WHC-SD-WM-CN-025, Rev. 0

APPENDIX B

Potasium Chloride MSDS 


\section{Appendix B - Potasium Chloride MSDS}

Sigma Chemical Co. P.0. Box 14508

St. Louis, MO 63178

Phone: $314-771-5765$
Aldrich Chemical Co., Inc. 1001 West St. Paul Milwaukee, WI 53233

Phone: $414-273-3850$
Fluka Chemical Corp. 980 South Second St. Ronkonkoma, NY 11779

Phone: 516-467-0980 
WHC-SD-WM-CN-025, Rev. O

KEEP TIGHTLY CLOSED.

STORE IN A COOL DRY PLACE.

SECIION 9. - - - - - PHYSICAL AND CHEMICAL PROPERTIES - - - - -

APPEARANCE AND ODOR

WHITE CRYSTALS

PHYSICAL PROPERTIES

MELTING POINT: $\quad 770 \mathrm{C}$

SPECIFIC GRAVITY: $\quad 1.984$

SECTION 10. - . - - -STABILITY AND REACTIVITY - . . - -

INCOMPATIBILITIES

STRONG OXIDIZING AGENTS

STRONG ACIDS

PROTECT FROM MOISTURE

HAZARDOUS COMBUSTION OR DECOMPOSITION PRODUCTS

HYDROGEN CHLORIDE GAS

SECTION 11. - - . - - - TOXICOLOGICAL INFORMATION - - . - -

ACUTE EFFECTS

HARMFUL IF SWALLOWED, INHALED, OR ABSORBED THROUGB SKIN.

CAUSES EYE AND SKIN IRRITAIION.

MATERIAL IS IRRITATING TO MUCOUS MDMBRANES AND UPPER

RESPIRATORY TRACT.

TO THE BEST OF OUR KNOWLEDGE, THE CHEMICAL, PHYSICAL, AND

TOXICOLOGICAL PROPERTIES HAVE NOT BEEN THOROUGHLY INVESTIGATED.

ADDITIONAL INFORMATION

INGESTION OF LARGE QUANTITIES CAN CAUSE WEAKNESS, GASTROINTESTINAL IRRITATION AND CIRCULATORY DISTURBANCES.

RTECS \#: TS8050000

POTASSIUM CHLORIDE

IRRITATION DATA

EYE-RBT 500 MG/24H MLD
28ZPAK $-, 8,72$

TOXICITY DATA

ORL-INF LDLO: 938 MG/KG/2D

ORL-MAN LDLO: $20 \mathrm{MG} / \mathrm{KG}$

ORL-RAT LD50:2600 MG/KG

JAMAAP $240,1339,78$

IPR-RAT LD50:660 MG/KG

LANCAO $2,919,80$

28ZPAK $-, 8,72$

IVN-RAT LD50:142 MG/KG

FCTXAV $3,597,65$

ORL-MUS LD50:1500 MG/KG

ARZNAD $14,1128,64$

IYKEDH $21,257,90$

IPR-MUS LDSO:1181 MG/KG

COREAF $256,1043,63$

IVN-MUS LD50:117 MG/KG

EJTXAZ $8,188,75$

ORL-GFG LD50:2500 MG/KG

JPETAB $35,1,29$

TARGET ORGAN DATA

BEHAVIORAL (CONVULSIONS OR EFFECT ON SEIZURE THRESHOLD)

BEHAVIORAL (CHANGE IN MOTOR ACTIVITY)

BEHAVIORAL (COMA)

CARDIAC (ARRYTHMIAS)

LUNGS, THORAX OR RESPIRATION (DYSPNAE)

LUNGS, THORAX OR RESPIRATION (CYANOSIS)

LUNGS, THORAX OR RESPIRATION (OTHER CHANGES)

GASTROINTESTINAL (NAUSEA OR VOMITING)

BLOOD (CHANGE IN CLOTTING FACTORS)

NUTRITIONAL AND GROSS METABOLIC (CHANGES IN: K)

ONLY SELECTED REGISTRY OF TOXIC EFFECTS OF CHEMICAL SUBSTANCES

(RTECS) DATA IS PRESENTED HERE. SEE ACTUAL ENTRY IN RTECS FOR COMPLETE INFORMATION

SECTION 12. - - - - - - - ECOLOGICAL INEORMATION - - - - - - DATA NOT YET AVAILABLE.

SECTION 23. . . . - DISPOSAL CONSIDERATIONS - ....... CONTACT A LICENSED PROFESSIONAL WASTE DISPOSAL SERVICE TO DISPOSE OF THIS MATERIAL.

OBSERVE ALL FEDERAL, STATE AND LOCAL ENVIRONMENTAL REGLLLATIONS.

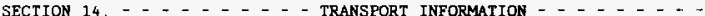
CONTACT FLUKA CHEMICAL, COMPANY FOR TRANSPORTATION INFORMATION.

SECTION $15 . \ldots$

EUROPEAN INFORMATION

HARMFUL

R $20 / 21 / 22$

HARMTUL BY INHALATION, IN CONTACT WITH SKIN AND IF SWALLOWED.

R $36 / 37 / 38$

IRRITATING TO EYES, RESPIRATORY SYSTEM AND SKIN.

S 26

IN CASE OF CONTACT WITH EYES, RINSE IMMEDIATEIY WITH PLENTY OF

WATER AND SEEK MEDICAL ADVICE. 
WHC-SD-WM-CN-025, Rev. 0

S 36

WEAR SUITABLE PROTECTIVE CLOTHING.

REVIEWS, STANDARDS, AND REGULATIONS

OEL $=$ MAK

NOHS 1974: HZD 60360; NIS 97; TNF 14471; NOS 88; TNE 122749

NOES 1983: HZD 60360 ; NIS 147 ; TNF 16061 ; NOS 125 ; TNE 387624 ; TFE

175287

EPA TSCA SECTION B(B) CHEMICAL INVENTORY

EPA TSCA TEST SUBMISSION (TSCATS) DATA BASE, OCTOBER 1995

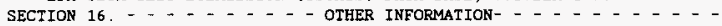

THE ABOVE INFORMATION IS BELIEVED TO BE CORRECT BUT DOES NOT FURPORT TO

BE ALL INCLUSIVE AND SHALL BE USED ONLY AS A GUIDE. SIGMA, ALDRICH,

FLUKA SHALL NOT BE HELD LIABLE FOR ANY DAMAGE RESULTING FRCM HANDLING

OR FROM CONTACT WITH THE ABOVE PRODUCT, SEE REVERSE SIDE OF INVOICE OR

PACKING SLIP FOR ADDITIONAL TERMS AND CONDITIONS OF SALE.

COPYRIGHT 1996 SIGMA CHEMICAL CO., ALDRICH CHEMICAL CO., INC.

FLUKA CHEMIE AG

LICENSE GRANTED TO MAKE UNLIMITED PAPER COPIES FOR INTERNAL USE ONLY 


\section{DISTRIBUTION COVERSHEET}

Author

R. D. Crowe
Addressee

G. F. Vargo, Jr.
WHC-SD-WM-CN-025

Rev. 0

subject: SURFACE MOISTURE MEASUREMENT SYSTEM ELECTROMAGNETIC INDUCTION PROBE CALIBRATION TECHNIQUE

INTERNAL DISTRIBUTION

\begin{tabular}{|c|c|c|c|c|}
\hline Approval & Date & Wame & Location & W/att \\
\hline & & R. D. Crowe (2) & $\mathrm{HO}-32$ & $x$ \\
\hline & & K. L. Drury & H5-09 & $x$ \\
\hline & & G. T. Dukelow & $S 7-14$ & $x$ \\
\hline & & D. L. Lessor & K7-15 & $x$ \\
\hline & & T. I. Stokes & L6-37 & $x$ \\
\hline & & G. F. Vargo, Jr. & H5-09 & $x$ \\
\hline & & A. E. Waltar & $\mathrm{H} 0-32$ & $x$ \\
\hline & & W. D. Wittekind & $\mathrm{HO}-32$ & $x$ \\
\hline & & $\begin{array}{l}\text { Central Files } \\
\text { Original }+1 \text { copy }\end{array}$ & $\begin{array}{r}+8-04 \\
43-88 \\
k_{N}\end{array}$ & $\begin{array}{l}x \\
x\end{array}$ \\
\hline
\end{tabular}

